\title{
School Counsellor Services in the Middle of the Pandemic COVID-19 by Using Social Media and Virtual Classes
}

\author{
Riskiyana Prihatiningsih*, Henny Indreswari \\ Bimbingan dan Konseling \\ Universitas Negeri Malang \\ Malang, Indonesia \\ *Riskiyana.prihatiningsih.fip@um.ac.id, \\ henny.indreswari.fip@um.ac.id
}

\author{
Dhara Alim Cendekia \\ Desain Komunikasi Visual \\ Universitas Negeri Malang \\ Malang, Indonesia \\ Dhara.alim.fs@um.ac.id
}

\begin{abstract}
The COVID-19 pandemic presents new challenges for school counsellors to continue to provide effective and optimal services even though they cannot meet face to face with students. The use of social media and virtual classes are two alternatives that can be used by school counsellors in providing services. The focus of this research is to provide an overview of the adaptability and skills of counsellors in implementing Counsellor Service (BK) during the COVID-19 pandemic through social media and virtual classes. The research method used was a survey with a population of 150 counsellors in East Java. Based on the survey results, the two main platforms used by school counsellors in implementing Counsellor Service (BK) in schools are WhatsApp and Google Classroom. The use of the two platforms was chosen based on the student's ease of access and features that were not too complicated for the counsellor to use.
\end{abstract}

Keywords—school counsellor services, pandemic COVID-19, school counsellor online services

\section{INTRODUCTION}

Counsellor Service (BK) is an integral part of the learning process in schools, it is part of the support system which is a component of Counsellor Service (BK) in schools [1]. During a pandemic era where students have to study from home, Counsellor Service (BK) should ideally adapt to this change by providing virtual services. The implementation of Virtual Counsellor Service (BK) requires the ability to use the right technology, and properly packages the service materials for smooth function of Guidance and Counselling Services (BK) during the pandemic era, which is developing and expanding student potentials and being a mediator for students to find solutions to problems encountered during the pandemic [2].

The competence of counsellors to implement virtual Counsellor Service (BK) during the pandemic is the key point. The ability of school counsellors to be involved in the application of computer technology and technology is required to be mastered [3]. Therefore, the Counsellor Service (BK) process can run properly and make it easier the Service (BK) to provide dynamic Counsellor Service (BK) so that students will not feel bored [4].

The onsite-conditions, the competence of counsellors in the use of technology are very diverse so that the Counsellor Service (BK) process during the pandemic also varies. Some counsellors simply use social media such as WhatApps or Facebook, while there are counsellors who use YouTube Channel as Counsellor Service (BK) media during the pandemic era. In some schools, Counsellor Service (BK) do not run properly due to the inability of the counsellors to provide services with media accessible to students, and reluctance to provide services for considering students are tired of the learning process from subject teachers.

Therefore, it is interesting to find out an overview of the implementation of Counsellor Service (BK) carried out during the pandemic carried out through social media and virtual classes.

\section{METHODS}

\section{A. Participant and Procedure}

The survey was conducted on the 163 counsellors' school spread across East Java. The survey was conducted using google form. The questions asked were the types of platforms used in Counsellor Service (BK) during the pandemic and the level of service satisfaction carried out during the pandemic. The survey was conducted between August and September 2020 .

\section{B. Data Analysis}

Survey responses were described using frequencies and means. Chi-square, ANOVA, and t-tests were performed as appropriate for comparisons between demographics and survey responses of interest. Missing or unknown responses were excluded in analyses. Comparisons involving specialty used the primary specialty, defined as $>50 \%$ effort being dedicated to 
that specialty. Analyses were considered exploratory and conducted at the 0.05 significance level using SPPS.

\section{RESULTS}

Based on the participant data on Table.1, those who participated in the survey were 163 participants consisting of 39 men and 124 women, and were categorized as having served as school counsellors for a long time and came from the distribution from junior high school and senior high school level and the equivalent.

TABLE I. DATA PARTICIPANT

\begin{tabular}{|l|l|l|}
\hline \multicolumn{1}{|c|}{ Gender } & & \multicolumn{1}{c|}{ Percentage } \\
\hline Male & 39 & \\
\hline Female & 124 & 76.9 \\
\hline Term of Service & & \\
\hline$>$ 15 Years & 29 & 17.79 \\
\hline 10 -15 years & 46 & 28.22 \\
\hline 4 - 9 Years & 64 & 39.26 \\
\hline 1-3 Years & 16 & 9.81 \\
\hline$<1$ year & 8 & $4-9$ \\
\hline School Level & & \\
\hline Middle School & 122 & 74.84 \\
\hline High school & 41 & 25.15 \\
\hline
\end{tabular}

Based on the number of participant's $n=163$, most school counsellors with a term of service spanning between $4-9$ years, are 64 people, followed by 10 - 15 years with the total number of 46 people, the term of service of more than 15 years is 29 people, and the consecutive term of service of 1 - 3 and less than 1 year are 16 and 8 people. School-level of the participants involved are from junior high school level (SMP) and equivalent, which is about 122 counsellors, and the others are 41 participants from senior high school level (SMA) and equivalent.

\section{A. Selection of Counsellor Service Platform and Implementation}

Based on the survey results, the counsellor uses media in carrying out services during the pandemic. In table 2 there is an overview of the use of platforms mostly used by counsellors in schools.

TABLE II. SERVICE MEDIA SELECTION DATA

\begin{tabular}{|l|l|l|}
\hline Platform Name & \multicolumn{1}{|c|}{ Total } & \multicolumn{1}{c|}{ Percentage } \\
\hline WhatsApps & 158 & 99,4 \\
\hline Instagram & 51 & 32,1 \\
\hline Telegram & 20 & 12,6 \\
\hline Youtube & 75 & 47,2 \\
\hline Tik Tok & 6 & 3,8 \\
\hline
\end{tabular}

Most of the counsellors used WhatsApp, which is 99.4 per cent as a Counsellor Service (BK) media during the pandemic. 75 people from 163 participants used YouTube as Counsellor
Service (BK) media, which is in the second position media used by counsellors. Next is Instagram 32, 1 per cent, Telegram 12.6 and TikTok 3.8 per cent.

In addition to social media-based platforms, counsellors carry out Counsellor Service (BK) using virtual classes. In the table. 3 there is a virtual class description of several platforms used by the counsellor.

TABLE III. VIRTUAl Class PlatForm SElECTION DATA

\begin{tabular}{|l|l|l|}
\hline \multicolumn{1}{|c|}{ Name } & \multicolumn{1}{c|}{ Total } & \multicolumn{1}{c|}{ Percentage } \\
\hline Edmodo & 5 & 3,1 \\
\hline Google Classroom & 107 & 65,6 \\
\hline Schoology & 2 & 1,2 \\
\hline Microsoft Teams & 16 & 9,8 \\
\hline
\end{tabular}

Other than the use of WhatsApp as virtual classes for a service media, counsellors also used virtual classes from several platforms, including Edmodo 3.1 per cent, Google classroom 65.6 per cent, Schoology 1.2 per cent, and Microsoft Teams 9.8 per cent

\section{B. Counsellor Service (BK) Assessment}

Counsellor Service (BK) carried out by school counsellors during the pandemic period obtain a mean score of 3.13 for collaborating with subject teachers or service influencers to attract student interest. The ability of the counsellor to create online-based services obtained a rating of 3.12 and 3.33 for the role of the counsellor as a reference source for subject teachers to find out the latest news from students. Based on the total number of participant's $\mathrm{N}=163$ with a maximum value of 5 and a minimum of 1 , it can be concluded that the Counsellor Service (BK) assessment during the pandemic period was still low.

\section{The Relation between Term of Service and Service Delivery}

Based on the results of the Chi-square analysis of the term of service and the service delivery as a whole was $0.340,0.693$, 0.893 with a standard deviation of 132 . So that the Chi-square count is < than the Chi-square table which is 132. Therefore, $\mathrm{H}_{0}$ is rejected, thus it is concluded that there is no relation between the term of service and the service delivery.

ANOVA analysts with significance results of $0.667,0.553$, and 0.848 which are $>$ than 0.5 , concluded that the service collaboration, the ability of the counsellor to create onlinebased services, and the role of the counsellor as a reference source for subject teachers to find out the latest news from students are different things in the Counsellor Service (BK) delivery.

\section{DISCUSSION}

Several previous studies stated many obstacles in delivering online services [5,6]. The obstacles experienced by counsellors were surely happened due to many reasons, such as 
technological difficulties, communication barriers, and the counsellor's delay in learning the latest technology [6-8]. Other factors causing the non-optimal online services is the lack of facilities students have for online study since not all students have smartphones or computers as their online learning media. Apart from that, another factor is the unfordable internet quote for all students $[9,10]$. So it is necessary to develop the media to make an effective Counsellor Service (BK) delivery during the pandemic [11].

The implementation of Guidance and Counselling service, which is inseparable from the collaboration and support of the stakeholder system, should be well implemented in the current pandemic conditions. The effective Counsellor Service (BK) program is a collaborative effort between school counsellors, families, communities' stakeholders and other educators in creating an environment that produces a positive impact on student achievement [12]. During the pandemic, Counsellor Service (BK) programs must consider the service objectives and its continuation. In the pandemic, with physical restrictions, the use of technology shall be an alternative to deliver Counsellor Service (BK). The counsellor must understand the function of technology to increase the professionalism of the counsellor. The implementation of technology in guidance and Counselling service must pay attention to the functions of the technology itself [13]. Collaboration in implementing Counsellor Service (BK) can increase the service effectiveness and achieve Guidance and Counselling (BK) program objectives $[14,15]$.

The use of technology as a media in assisting the process of carrying out Counselling is the ease needed by students during the current pandemic. This helps students solve their problems by doing online Counselling or remote Counselling. The use of technology is not only easier for the counselee but also the counsellor [16]. The ability to use technology in Counsellor Service (BK) during the pandemic has an impact on counsellors with long-term work experience and tends not to have a significant effect on the implementation of Counsellor Service (BK) during the pandemic to the counsellors with relatively new work experience. Teaching counsellors about the use of technology in Counsellor Service (BK) is important to improve service effectiveness and counsellor professionalism [17]. In the future, online-based Counsellor Service (BK) will be a choice for students to get Counsellor Service (BK) in schools along with the development of time regardless of the conditions of the Covid-19 pandemic [18].

Presenting a counsellor to the daily lives of students who are currently in their respective homes and become an oasis for all the emotional turmoil caused during a stinging pandemic is possible with technology. Technology can help in making communication to the counselee with a platform that makes the counselee comfortable without space, place and time barriers [19]. The use of technology in Counsellor Service (BK) needs should be in a harmony with the quality of Counsellor Service (BK) content provided. Counsellor Service (BK) quality standards that are implemented virtually are an important concern for effective, efficient service delivery and achieves the objectives of Counsellor Service (BK) [20].

Technology-based Counsellor Service (BK) have been widely implemented, one of which is E-Counselling as responsive and curative service action [21]. The use of technology as a medium in helping the process of carrying out Counselling is the convenience needed by students in today's digital era. This helps students solve their problems by doing online Counselling or remote Counselling. The use of technology not only makes it easier for the counselee or, in this case, is students but also for the counsellor [16]. The use of online Counselling in tertiary institutions can cover all the problems experienced by students, including the provision of several aspects of Counselling through technology, through applications such as e-mail, access to web-based information, course registration, academic advisors, and career guidance [22]. The implementation of online Counselling is considered the most suitable to be applied in today's digital era with suitability including ethical considerations, client satisfaction, and treatment outcomes [23]

In addition to Counselling services, the implementation of technology-based Counsellor Service (BK) in schools is providable with platforms, such as Google Classroom, Edmodo, Schoology and other similar platforms. The use of technology in the implementation of guidance can be a tool, alternative and agent of change [24]. The current pandemic condition requires the Counsellor Service (BK) to keep making innovation and competing to answer challenges so that Counsellor Service (BK) conveyed to students can be an effort to build stability and resilience in the face of the COVID-19 pandemic [25].

\section{CONCLUSION}

The implementation of Online Counsellor Service (BK) system during the Covid-19 pandemic has not been run optimally. This is due to the factor of the low level of technology utilization so that the service is less varied to foster student interest. The low collaboration in the implementation of services that have an impact on Counsellor Service (BK) is not a reference for subject teachers and form teachers to perceive the current conditions of students. Understanding of appropriate media utilization and data-based service strategies will support the implementation of Counsellor Service (BK) during the pandemic or post-pandemic conditions where Counsellor Service (BK) with an online system are an alternative Counsellor Service (BK) choice for students.

\section{REFERENCES}

[1] Permendikbud No 111 Tahun, Peraturan Menteri Pendidikan dan Kebudayaan Republik Indonesia tentang Bimbingan dan Konseling pada Pendidikan Dasar dan Pendidikan Menengah. Pedoman Evaluasi Kurikulum, 2014.

[2] H. Kamaluddin, "Bimbingan dan konseling sekolah," Jurnal Pendidikan Dan Kebudayaan, vol. 17, no. 4, pp. 447-454, 2011. 
[3] S.M. Van Horn and R.D. Myrick, "Computer technology and the 21st century school counselor," Professional School Counseling, vol. 5, no. 2, pp. $124,2001$.

[4] T. Triyono and R.D. Febriani, "Pentingnya Pemanfaatan Teknologi Informasi oleh Guru Bimbingan dan Konseling," JUANG: Jurnal Wahana Konseling, vol. 1, no. 2, pp. 74-83, 2018.

[5] S.E. Greenberg, E. Boothe, C.L. Delaney, R. Noss and S.A. Cohen, "Genetic Counseling Service Delivery Models in the United States: Assessment of changes in use from 2010 to 2017," Journal of Genetic Counseling, vol. 29, no. 6, pp. 1126-1141, 2020.

[6] H.A. Zierhut, I.M. MacFarlane, Z. Ahmed and J. Davies, "Genetic counselors' experiences and interest in telegenetics and remote counseling," Journal of Genetic Counseling, vol. 27, no. 2, pp. 329-338, 2018.

[7] T. Anderson, The theory and practice of online learning. Athabasca University Press, 2008.

[8] R.A. Pangondian, P.I. Santosa and E. Nugroho, "Faktor-faktor yang mempengaruhi kesuksesan pembelajaran daring dalam revolusi industri 4.0," Seminar Nasional Teknologi Komputer \& Sains (SAINTEKS), vol. 1, no. 1,2019 .

[9] N. Taradisa, Kendala Yang Dihadapi Guru Mengajar Daring Pada Masa Pandemi Covid-19 Di Min 5 Banda Aceh. Kendala Yang Dihadapi Guru Mengajar Daring Pada Masa Pandemi Covid-19 Di Min 5 Banda Aceh, $1-11,2020$.

[10] A. Wardani and Y. Ayriza, "Analisis kendala orang tua dalam mendampingi anak belajar di rumah pada masa pandemi Covid-19," Jurnal Obsesi: Jurnal Pendidikan Anak Usia Dini, vol. 5, no. 1, pp. 772 $782,2020$.

[11] S. Alhadi, A. Supriyanto and D.A.M. Dina, "Media in guidance and counseling services: a tool and innovation for school counselor," SCHOULID: Indonesian Journal of School Counseling, vol. 1, no. 1, pp. 6-11, 2016.

[12] ASCA, "The ASCA National Model: A Framework for School Counseling Programs," Professional School Counseling, 2003.

[13] E. Susanto, "Technology Guidance and Counselling: Implementation Theory in Practice, Development and Experience," Proceeding of International Seminar and Workshop on Guidance and Counseling, 2014.
[14] P.B. Caraka, E.S. Nindiya and A.R. Fuad, Improving Quality Of Education Through Collaboration System In The Perspective Of Comprehensive Guidance And Counseling, 2016.

[15] H. Hastiani, S. Sugiyo and E. Purwanto, "Guidance And Counseling Teacher And Subject Teacher Collaboration Model Increasing The Interpersonal Communication Skill Of Special Intelligent Students," Jurnal Bimbingan Konseling, vol. 3, no. 1, 2014.

[16] D. Capuzzi and D.R. Gross, Introduction to the Counseling Profession (Eighth Edition). Cognella, Incorporated, 2018.

[17] L. Lazuras and A. Dokou, "Mental health professionals' acceptance of online counseling," Technology in Society, vol. 44, pp. 10-14, 2016.

[18] K.P. Wong, G. Bonn, C.L. Tam and C.P. Wong, "Preferences for online and/or face-to-face counseling among university students in Malaysia," Frontiers in Psychology, vol. 9, pp. 64, 2018

[19] R.A. Sabella and B.L. Booker, "Using technology to promote your guidance and counseling program among stake holders," Professional School Counseling, vol. 6, no. 3, pp. 206-213, 2003.

[20] M. Offer and J.P. Sampson Jr, "Quality in the content and use of information and communications technology in guidance," British Journal of Guidance and Counselling, vol. 27, no. 4, pp. 501-516, 1999.

[21] I. Ifdil and Z. Ardi, "Konseling Online Sebagai Salah Satu Bentuk Pelayanan E-konseling," Jurnal Konseling Dan Pendidikan, 2013.

[22] M.F. Maples and S. Han, "Cybercounseling in the United States and South Korea: Implications for counseling college students of the millennial generation and the networked generation," Journal of Counseling and Development, 2008

[23] L. Murphy, D. Mitchell and R. Hallett, "A comparison of client characteristics in cyber and In- person counseling," Annual Review of CyberTherapy and Telemedicine, 2011.

[24] N.D. Oye, M.C. Obi, T.N. Mohd and A. Bernice, "Guidance and Counseling in Nigerian Secondary Schools: The Role of ICT," International Journal of Modern Education \& Computer Science, vol. 4, no. 8,2012

[25] World Health Organization, COVID-19: Operational guidance for maintaining essential health services during an outbreak - Interim guidance 25 March 2020. World Health Organization (WHO), 2020. 